\title{
EU Common Foreign and Security Policy and Bosnia and Herzegovina
}

\author{
La Politica Exteriory de Seguridad Común de la UE \\ y Bosnia y Herzegovina
}

\author{
Selma Delalić \\ Assistant Profesor of International Relations and European Studies \\ International Burch University \\ Sarajevo, Bosnia and Herzegovina \\ selma.delalic@ibu.edu.ba
}

\begin{abstract}
The beginning of modern history and the subsequent war in Bosnia and Herzegovina coincide with the institutional beginnings of the European Union common foreign and security policy. At that time, Europe did not have a single position, nor could it have achieved a political consensus on any issue. In addition, it lacked appropriate instruments, as well as readiness and willingness to actively engage to put an end to war in $\mathrm{BiH}$. The war in $\mathrm{BiH}$ was stopped, however, thanks to the efforts of the United States. This was a crucial moment for Europe to modify its common foreign and security policy. The European Union has passed a thorny path of establishing common foreign and security policy. On this path, however, the EU has experienced some progress and achieved good results, although not sufficient, just as BiH has made some progress in reforms. In order for $\mathrm{BiH}$ to joint the family of modern democratic countries, it will need a stronger engagement of the European Union and its more decisive common foreign and security policy, because only together we can cope with global challenges. Peace and prosperity in Bosnia and Herzegovina will also help build free and stable Europe.
\end{abstract}

Keywords: Bosnia and Herzegovina, European Union, Common Foreign and Security Policy, NATO, United States, International Community, reforms.
Resumen: El comienzo de la historia moderna y la guerra posterior en Bosnia y Herzegovina coinciden con los inicios institucionales de la Política Exterior y de Seguridad Común de la Unión Europea. En ese momento, Europa no tenía una posición única, ni podría haber logrado un consenso político sobre ningún tema. Además, carecía de los instrumentos adecuados, así como de la disposición y la voluntad de comprometerse activamente para poner fin a la guerra en Bosnia y Herzegovina. Sin embargo, la guerra en Bosnia y Herzegovina se detuvo gracias a los esfuerzos de los Estados Unidos. Fue un momento crucial para que Europa modificase su Política Exterior y de Seguridad Común. La Unión Europea ha recorrido un camino difícil para establecer esta política. A largo de este camino, la UE ha experimentado algún progreso y logrado buenos resultados, aunque no es suficiente. Igualmente Bosnia y Herzegovina ha hecho algún progreso con sus reformas jurídicas internas para unirse así a la familia de los países democráticos modernos. Necesitará, no obstante, un mayor compromiso de la UE y una PESC más decisiva para poder hacer frente a los desafíos globales. La paz y la prosperidad en Bosnia y Herzegovina también ayudarán a construir una Europa libre y estable.

Palabras clave: Bosnia y Herzegovina, Unión Europea, Política Exterior y de Seguridad Común, OTAN, Estado Unidos, la Comunidad Internacional, reformas

\footnotetext{
Summary: INTRODUCTION. 1. COMMON FOREIGN AND SECURITY POLICY OF THE EU AND THE BEGINNING OF WAR IN BOSNIA AND HERZEGOVINA. 2. DAYTON PEACE AGREEMENT AND THE UPGRADING OF THE EU'S COMMON FOREIGN AND SECURITY POLICY. 2.1. EU Treaties of Amsterdam, Nice and Lisbon. 2.1.a. The Treaty of Amsterdam. 2.1.b. The Treaty of Nice. 2.1.c. The Treaty of Lisbon. 3. INTERNATIONAL COMMUNITY AND THE IMPLEMENTATION OF THE DAYTON PEACE AGREEMENT. 3.1. Implementation of the military provisions of the Agreement. 4. EU COMMON SECURITY AND DEFENCE POLICY. 4.1. Bosnia and Herzegovina and membership in NATO and the European Union. 5. BOSNIA AND HERZEGOVINA'S BRUSSELS PHASE. 5.1. The New Millennium U.S. Foreign Policy towards Bosnia and Herzegovina. CONCLUSION.
} 


\section{INTRODUCTION}

F ollowing the dissolution of the Soviet Union and the end of the Cold War, the world entered a new stage in the development of international relations, marked by the transition from the bipolar system to unipolar ${ }^{1}$ [which increasingly takes on the appearance of a multipolar one] and in which a large number of states have begun to redefine their national and security interests, taking into account the changed geopolitical and geoeconomic environment. ${ }^{2}$ New, powerful, primarily non-state actors, both in the sphere of politics and economy, as well as in the sphere of security, have boldly stepped onto the world scene. ${ }^{3}$ All of these changes have been further supported by, and also accelerated by the globalization, which had its true momentum at the end of the $20^{\text {th }}$ century and the beginning of the new millennium. ${ }^{4}$

The beginning of the latest ${ }^{5}$ history of Bosnia and Herzegovina coincides with contemporary development of international relations. ${ }^{6}$ The modern history of $\mathrm{BiH}$ could be marked by the period from its independence in relation to the former Socialist Federal Republic of Yugoslavia ${ }^{7}$ and its recognition by

1 Rauthammer, Ch., The Unipolar Moment, Foreign Affairs, vol. 70, No. 1, 1991, p. 17; and Fettweis, Ch., Sir Halford Mackinder, Geopolitics, and Policymaking in the 21st Century, U.S. Army War College, vol. 30, Issue 2, 2000, pp. 223-245.

2 Chomski, N., Stari i novi svjetski poretci, Zagreb, Naklada Jesenski i Turk, 2004, pp. 3-56.

3 BREMmer, I., The end of the free market: who wins the war between states and corporations?, New York, Portfolio, 2010, pp. 54-67.

4 Duraković, N., Međunarodni odnosi, Fakultet političkih nauka, Pravni fakultet, Sarajevo, 2009, pp. 33-58.

5 The emphasis on the latest history of Bosnia and Herzegovina is not without reason. Namely, Bosnia and Herzegovina is a country with almost a thousand-year history, as evidenced, inter alia, by the Charter of Kulin Ban of 1189 . By this Charter, the then sovereign of the Bosnian state ban Kulin guaranteed to the Dubrovnik traders the safe movement and trade in his country. The Charter of Kulin Ban is the oldest preserved diplomatic document of a medieval Bosnian state that is commonly referred to as the birth certificate of Bosnian statehood. For more information, see: IMAMOVIĆ, E., Korijeni Bosne i Bosanstva, Sarajevo, Međunarodni centar za mir, 1995. IMAMOVIĆ, E., Šta za Bosnu znači Povelja Kulina bana, bttp://ins.ba/bs/article/1313/ dr-enver-imamovic-sta-za-bosnu-znaci-povelja-kulina-bana, accessed 10 March 2018.

6 Ljubijankić, I., «New world order and Bosnia and Herzegovina», fournal of Muslim Minority Affairs, 1996, Editorial, p. 12

7 On March 1, 1992, 99.44\% of Bosnians and Herzegovinians out of 2,073,568 citizens who went to the referendum on the independence of Bosnia and Herzegovina, declared themselves for the sovereign and independent state of Bosnia and Herzegovina, i.e. independent in relation to the Socialist Federal Republic of Yugoslavia. Shortly thereafter, a brutal aggression on Bosnia and Herzegovina began in which more than 100,000 Bosniaks lost their lives, between 35,000 and 50,000 Bosniak girls and women were raped, and 1,600 children were killed just in Sarajevo during the siege of the capital of Bosnia and Herzegovina that lasted 1425 days. 
the international community as an independent and sovereign state in 1992 to the most recent days. During this period, $\mathrm{BiH}$ has undergone significant restructuring in its political and constitutional-legal system as compared to its former political history and legal constitution. ${ }^{8}$

The aggression ${ }^{9}$ against $\mathrm{BiH}$ began shortly after the recognition of Bosnia and Herzegovina by the international community and the United Nations. From 1992 to 1994, the European Union tried to stop the war in $\mathrm{BiH}$ by various diplomatic means, including international peace conferences that were all unsuccessful. This lasted until the beginning of 1994 when the US Administration led by the then President Bill Clinton ${ }^{10}$ undertook a diplomatic initiative to resolve the Bosnian issue, which resulted in the establishment of the Federation of Bosnia and Herzegovina by the Washington Agreement of March 31, 1994 and the following year by the Dayton Agreement which was concluded on 21 November 1995 in the United States and signed in Paris on December 14, the same year, which ended a brutal four-year aggression. ${ }^{11}$

Dayton Peace Agreement marked the end of war, but at the same time, it signified the beginning of troubles for Bosnia and Herzegovina, and its socio-political and legal constitution, as well as internal and external integration of the state. ${ }^{12}$ Bosnia and Herzegovina underwent multiple transitions, from war to peace, from planned to market economy, and from one-party to multi-party system. The post-Dayton period of $\mathrm{BiH}$, that is, the period since

8 Glenny, M., The Fall of Yugoslavia, Harmondsworth, Penguin, 1996, pp. 82-177.

9 It is very common to read that the war in Bosnia and Herzegovina, in the early 1990s, was a civil war. True, Bosnia and Serbia were once republics that, together with, Slovenia, Croatia, Montenegro, Macedonia, Kosovo and Macedonia, constituted one state - the Socialist Federal Republic of Yugoslavia. However, when the Yugoslav People's Army and paramilitary units of Serbia carried out a military attack on Bosnia and Herzegovina, it was already an independent and internationally recognized state. In other words, the war in Bosnia in Herzegovina was the classical aggression of the state of Serbia against the state of Bosnia and Herzegovina, it was an interstate, not a civil war. For more information see IMAMović, M., Agresija na Bosnu i Hercegovinu i borba za njen opstanak: 1992-1995, Pravni fakultet Univerziteta u Sarajevu, Sarajevo, 1997, p. 354.

10 Butfoy, A., «The Rise and Fall of Missile Diplomacy? President Clinton and the 'Revolution in military affairs'», in Retrospect, Australian fournal of Politics and History, Blackwell Publishing, Boston, 2006, pp. 112-145.

11 BURG, S. L., The War in Bosnia and Herzegovina: ethnic conflict and international intervention, Armonk, M.E. Sharpe, New York, 1998, pp. 82-90.

12 BeLloni, R., «Civil Society and Peace Building in Bosnia and Herzegovina», Fournal of Peace Research 38, International Peace Research Institute, Oslo, March 2001, pp. 34-83. 
the signing of the Dayton Agreement to date, has been marked by reform processes, democratization of society, building of democratic institutions and the establishment of political pluralism. In these processes, international community had played a key role. No reform in the post-Dayton life of Bosnia and Herzegovina was carried out without the influence and engagement of the international community, which was crucial for the preservation of territorial integrity, sovereignty, international subjectivity and political independence of BiH. ${ }^{13}$

The irresponsible Bosnian-Herzegovinian political elite could not reach political agreement on the largest number of issues. Consequently, legal solutions and decisions were made and laws imposed by the High Representative in Bosnia and Herzegovina, especially with regard to laws regulating or establishing central state institutions. The engagement of the international community was crucial for the internal and external integration and economic reconstruction of the country.

However, everything that has been done so far by the international community in Bosnia and Herzegovina is unfortunately not nearly enough for Bosnia and Herzegovina to join the family of modern European countries where it belongs. ${ }^{14}$ Namely, the Dayton Agreement ended the war, but unfortunately a functional state was not established. «Richard Holbrooke, who worked on the Dayton Agreement, endeavoured to stop the war. This agreement was not meant to establish a functioning European economy. ${ }^{15}$ The best testimony on what the Dayton Agreement meant for Bosnia and Herzegovina at the time of its signing, and what it means today is given by the former High Representative in Bosnia and Herzegovina, Wolfgang Petritsch «At the time of the signing, it [the Dayton Agreement] was a «the rescue belt» of Bosnia and Herzegovina, and has long since become a «mad shirt». ${ }^{16}$

In order for Bosnia and Herzegovina to move along the path of modern, democratic Western European countries, or to become a modern European state, in which the efficient functioning of state institutions will be

13 Pejanović, M., Politički razvoj Bosne i Hercegovine u postdejtonskom periodu, Sarajevo, October 2005, pp. 70-200.

14 NowaK, M., Bosna i Hercegovina na putu ka modernoj državi? Perspektive $i$ prepreke - Neuspjeb Daytona? Fondacija Heinrich Boll, Sarajevo, 2005, pp. 102-190.

15 Interview by Richard Sclar, Dnevni avazi, 21 October 2004.

16 Petritsch, W., Večernji list, 28 January 2005. 
established, it is necessary to adopt European standards in the political, economic and social spheres. ${ }^{17}$ Bearing in mind the fact that, over the past twenty years, the irresponsible $\mathrm{BiH}$ political establishment has shown, to a lesser or greater extent, unpreparedness for reforms, this goal can only be achieved with a stronger engagement of the European Union through a more determined foreign and security policy towards Bosnia and Herzegovina.

\section{COMMON FOREIGN AND SECURITY POLICY OF THE EU AND THE BEGINNING OF WAR IN BOSNIA AND HERZEGOVINA}

The war in Bosnia and Herzegovina seems to have occurred at the wrong time, too early for Europe to take decisive steps to stop the bloodshed. Namely, at the beginning of the aggression against Bosnia and Herzegovina, the European Economic Community (EEA) was transformed into the European Union by the Maastricht Treaty ${ }^{18}$ signed on February 7, 1992. [The Agreement entered into force on November 1, 1993]. The same Treaty established common EU foreign and security policy as the second pillar of the Treaty, including the possible development of a common defence policy, which would eventually result in the formation of a joint defence.

17 Russ, B., «Can foreigners fix Bosnia?», Christian Science Monitor, 19 September 2003, p. 67.

18 The Maastricht Treaty specifies in detail the actions of member states in the framework of common foreign and security policy. It thus states that member states will inform and consult each other within the Council in relation to all matters relating to foreign and security policy of general interest, and the Council will, whenever deems necessary, define a common policy. Member States will ensure the coherence of national policies with common positions that they will protect in international organizations and international conferences. It further states that member states will support the Union's foreign and security policy, actively and unconditionally, in the spirit of loyalty and mutual solidarity, and will refrain from any activity that is contrary to the interests of the Union or could lessen its effectiveness as cohesive power in international relations. Regarding the security policy, Article J.4 of the Treaty defines that the task of the West European Union (WEU) is to elaborate and implement the decisions and actions of the Union relating to the defence but will not prejudice the specific character of the security and defence policies of the member states, that it will respect their obligations within the NATO alliance, and that it will be compatible with the common security and defence policy defined in this framework. For more information see Council of the European Communities (1992), Treaty on European Union, Luxembourg: Office for Official Publications of the European Communities available at https://europa.eu/european-union/sites/europaeu/ files/docs/body/treaty_on_european_union_en.pdf. 
The main objectives of the common foreign and security policy, drafted and implemented by both the European Council, ${ }^{19}$ and all Member States are as follows:

- «Protection of common values, fundamental interests and independence of the Union;

- Strengthening the security of the Union and its Member States by all means;

- Preserving peace and strengthening international security in accordance with the principles of the UN Charter, the principles of the Helsinki Final Act and the objectives of the Paris Charter;

- Improvement of international cooperation;

- Development and consolidation of democracy and the rule of law, and respect for human rights and fundamental freedoms. $\gg^{20}$

The Maastricht Treaty has introduced another novelty: a consensus-based 'joint action' that will make co-operation among member states in the area of common foreign and security policy more effective. Joint action implies implementation of common, agreed EU policies. ${ }^{21}$

The Common Foreign and Security Policy of the European Union is the area in which EU Member States have been, from the very beginning, facing the greatest, and the most serous challenges. The reason lies primarily in the fact that Member States reluctantly renounce their own sovereignty ${ }^{22}$

19 The Treaty specifies that the diplomatic and consular missions of the Member States and the Delegation of the Commission in third countries and international conferences and their representatives in international organizations will work together to ensure respect for and implementation of common positions and measures adopted by the Council. Council of the European Communities (1992), Treaty on European Union, Luxembourg: Office for Official Publications of the European Communities, Article J.6, p 129, available at https://europa.eu/european-union/sites/europaeu/files/docs/body/treaty_on_european_union_en.pdf.

20 Council of the European Communities (1992), Treaty on European Union, Luxembourg: Office for Official Publications of the European Communities, pp. 126,7, available at https://europa.eu/european-union/sites/europaeu/files/docs/body/treaty_on_european_union_en.pdf.

21 Gordon, Ph.H. (1997/8), EU's Uncommon Foreign Policy, The MIT Press, International Security, vol. 22, No. 3 (Winter 1997-1998), p. 82.

22 The legal system of the European Union is designed in a way that each member state renounces a part of the sovereignty in favour of transnational European institutions. With the enlargement and strengthening of the European Union, the areas in which policies were drafted and decisions were made at the level of European Union institutions also increased. Today, European Union institutions have exclusive competence in the field of: customs union, functioning of the internal market, monetary policy, conservation of marine biological resources, fishery, and trade. There are a number of areas in which EU institutions share competence with member states such as: economic, social and territorial cohesion, agriculture, environment, consumer protection, 
in order to strengthen common policies in the areas of greatest importance for their own countries - security and foreign affairs - not necessarily taking into account economic issues that undoubtedly occupy the highest place in the national priorities. ${ }^{23}$ The second reason lies in the fact that every EU member state has its own history, tradition, as well as national, foreign and security interests, which are often not mutually compatible or, worse, contradictory. It is precisely these policies that are at the same time the biggest stumbling block for the overall functioning of the European Union. ${ }^{24}$

As we can see, in the beginning of war in Bosnia and Herzegovina in 1992, the European Union did not have institutional capacities, nor did it have readiness and political will to actively engage in order to put the war to an end. According to Samuel Huntington, «The initial schemes of European construction erected on motives such as peace, progress, cultural self-esteem, solidarity, the commonality of ideas and aspirations were seriously shaken.» ${ }^{25}$ Europe was unfit to face the most serious crisis on its soil after the end of the Second World War.

Although the common foreign and security policy was institutionalized by the Maastricht Treaty, foreign policy cooperation between the European Union countries began in the 1970s in the framework of European Political Cooperation as well as the regular consultations of foreign ministers, harmonization of attitudes and agreement on common trends. However, two decades later, European diplomacy was extremely ineffective, ${ }^{26}$ it lacked adequate instruments, and the courage to undertake any decisive activity - it was almost

transport, energy and the area of freedom, security and justice. When it comes to a common foreign and security policy, the EU is responsible for defining and implementing activities in these areas, including common defence policy (art. 2) without reducing the responsibilities and competences of each member state in the formulation and implementation of its own foreign policy, the national diplomatic service, relations with third countries and participation in international organizations (Declaration on Common Foreign and Security Policy). However, every Member State that wishes to pursue activities under the common foreign and security policy is obliged to inform the Council, the EU High Representative for Foreign and Security Policy, and the Commission (art. 331), Treaty on European Union and the Treaty on the Functioning of the European Union with Protocol, Annexes, and Declarations, retrieved https://eur-lex. europa.eu/legal-content/EN/TXT/HTML/?uri=CELEX:12012E/TXT\&from=EN, accessed 30 July 2018)

23 Dannreuther, R., European Union Foreign and Security Policy: towards a neighborbood strategy, Routledge, Taylor \& Francis Group, 2004, pp. 66-133.

24 Ibid., p. 94.

25 Huntington, S. P., Sukob civilizacija i preustroj svjetskog poretka, Zagreb, 1998, p. 160.

26 Freedman, L., «Why the West Failed», Foreign Policy, No. 94, Winter 1994-95, pp. 18-62. 
completely absent at the crucial moment for the survival of one state and one nation.

Initially, the UN had a major role in resolving the crisis in Bosnia and Herzegovina. At the end of 1991, the UN declared, at the peace conference in The Hague, arms embargo to former Yugoslavia. The embargo almost completely tied hands of the then Army of the Republic of Bosnia and Herzegovina, which was fighting against the former Yugoslav People's Army, the fourth largest military force in Europe, and at the same time enabled the full military superiority of the Serb forces in Bosnia and Herzegovina, which had Yugoslav People's Army fighting on its side. Public opinion and decision-makers from Western countries have learned the horrors of the war in Bosnia and Herzegovina thanks to the courage of several Western reporters, their discovery of concentration camps in Bosnia and Herzegovina, and sending to the world the images of persecution, torture and the horrors that the inmates went through. In mid-August 1992, the United Nations decided to send 23,000 of its soldiers (UNPROFOR) whose primary task was the protection of humanitarian convoys. ${ }^{27}$

Unfortunately, UNPROFOR, this rather helpless UN mission, was unable to fulfill its mission and protect humanitarian convoys. After an Italian plane, which transported humanitarian aid to the citizens of the besieged Sarajevo, was crashed and after courageous journalists again unravelled how Bosnian Serbs were throwing cluster bombs onto civilians in unprotected settlements, the UN Security Council, with the support of the United States, issued a resolution imposing no fly zone over Bosnia and Herzegovina, ${ }^{28}$ leaving out unfortunately provisions that would ensure the implementation of the resolution. Instead, the resolution stated that if the Serbs continue to fly military planes, that the Security Council would «urgently consider further measures necessary to ensure no fly zone». ${ }^{29}$ As might have been expected, the resolution was systematically violated by the Bosnian Serbs, as hundreds of unauthorized helicopter, combat and transport aircraft flights were recorded. This was also the reason for the UN Security Council to issue a new resolution authorizing NATO airplanes to bring down any plane that violates the no fly zone above Bosnia and Herzegovi-

7 Voblenko, V.V., «Multinational Peacekeeping Operations in the Balkans: Past and Present», Military Thought, p. 25; and FousKas, V., «The European Dream, Debates», Fournal of Southern Europe and the Balkans, Carfax Publishing, Taylor and Francis Group, London, 2003, p. 40.

28 LEWIS, P., «UN Bans Flights in Bosnia but is Silent on Enforcement», New York Times, 10 October 1992, pp. 47-201.

29 Ibid., pp. 59-81. 
na. This was the first NATO mission in a country non-member of the Alliance, and it involved US, British, French and Dutch air force. ${ }^{30}$

As the war in Bosnia and Herzegovina continued, the helplessness and impotence of the UN peacekeeping force of UNPROFOR became more apparent. The most serious blow to UNPROFOR's credibility was their continued humiliation and hostage taking by the Serb forces. ${ }^{31}$ In early 1995 , European countries which contributed military staff to UNPROFOR, began to warn that they would withdraw their troops. ${ }^{32}$ After the fall of Srebrenica in July $1995,{ }^{33}$ their withdrawal became inevitable, and the shame was complete. ${ }^{34}$ The UN peacekeeping force was suspended, and in August 1995, Holbrooke's shuttle diplomacy ${ }^{35}$ began, after NATO forces had launched air strikes on Bosnian Serb military positions.

30 LEURDIJK, D. A., «Before and after Dayton: the UN and NATO in the former Yugoslavia», The World Quarterly, Taylor and Francis Group, London, 1997, pp. 208-299.

31 There were numerous cases of capturing and hostage taking of UNPROFOR soldiers, especially before the end of the war in Bosnia and Herzegovina, primarily with the aim of preventing NATO air strikes against the positions of the Army of Republika Srpska. I will mention only a few examples. In April 1994, the Republika Srpska Army broke a cease-fire agreement, and UNPROFOR urged NATO to intervene. In retaliation, Serbian troops captured 400 soldiers and officers of UNPROFOR. In late May 1995, members of the Republika Srpska Army disarmed and captured forty blue helmets in the Sarajevo municipality of Ilidza, only to release them twenty days later. That same year, in Pale near Sarajevo, several blue helmets were captured and bound to electric power pole. In addition, UNPROFOR vehicles were often exposed to gunfire and artillery fire by members Army of Republika Srpska.

32 LEWIS, p. 17.

33 On July 11, 1995, the Republika Srpska Army together with members of the paramilitary unit Scorpions, under the control of the Serbian Interior Ministry, committed genocide, the biggest crime since the Second World War. In the genocide in Srebrenica, 8372 Bosniak men and boys aged 12 to 77 were killed. More than twenty years after the genocide had been committed, the remains of all victims have not yet been found in numerous mass graves in Bosnia and Herzegovina. It is important to note that at that time Srebrenica was a UN protected zone and that the mentioned units had conquered Srebrenica in the presence of the UNPROFOR Dutch units.

34 At the end of 1994, NATO decided to intervene to help withdrawal of blue helmets. The US administration, led by President Bill Clinton, confirmed this commitment, so that NATO military strategic planners began to work on the Operational Plan 40104. Based on this plan, the evacuation force was composed of 60,000 people, of which the Americans accounted for a third - 20,000 soldiers. For more information see: BASs, W., The Triage of Dayton, Foreign Affairs, Council on Foreign Relations, New York, September/October 1998.

35 The Dayton Agreement was the result of the so-called shuttle diplomacy, or the initial strong diplomatic efforts of the American diplomat, professor, and publicist, Richard Holbrooke and his team. Shuttle diplomacy, perhaps the most dynamic form of diplomacy, involves negotiating and reconciling the demands of the warring parties in an extremely dynamic environment and frequent travel, so the team often had breakfast in one country, lunch in the other, and dinner in the third country. 
Why did the international community wait four long years to stop the war in Bosnia and Herzegovina? The European Union did not have a single position, nor could it have achieved a political consensus on almost any issue, including the war in Bosnia and Herzegovina. In the period 19921995, numerous, unsuccessful European initiatives had continued, which unfortunately favoured a division of the state along ethnic lines: Lord Carrington's and Lord Owen's initiative, ${ }^{36}$ the Kutiljero 1992 peace proposals, Vance-Owen's 1993, and Owen-Stoltenberg's 1994, peace plans. ${ }^{37}$ «Regardless of some of the joint European peace initiatives, it was not possible, at that time, to gather two EU members who shared similar positions, let alone to draft a common foreign policy towards the crisis region. In spite of the lack of political will, the European Union and its member states did not have the strength to resolve the conflict in $\mathrm{BiH} . »^{38} \ll$ Integration in the field of foreign policy and defence has long been prevented by the deep division that existed between the Atlantists, first of all Britain and the Netherlands, countries which insisted on the key role of NATO, Euro-centrists, including France and Belgium, which advocated the creation of autonomous European armed forces and neutral states, Sweden, Finland, Austria and Ireland, which were not ready for any of the options [the tendency of preserving national sovereignty]. ${ }^{39}$

On the other hand, the Americans saw the war in Bosnia and Herzegovina as the European problem and considered that Bosnia and Herzegovina was an opportunity for the European Union to show initiative and unity within its common foreign and security policy, although they were unaware that their expectations were unrealistic and premature. «For the first time since the World War II, Washington has completely left the question of the security of the Balkan region to the Europeans. ${ }^{40}$

After several years of bloodshed, persecution, murder, rape, ethnic cleansing followed by inadequate European initiatives and even more inad-

36 Owen, D., Balkan Odyssey, New York: Book Harcourt Brace \& Company, cop. 1995, pp. 308466.

37 For more information about $\mathrm{BiH}$ peace plans of the international community see: Kasim, Begić, Bosna i Hercegovina od Vanceove misije do Daytonskog sporazuma (1991-1996), Bosanska knjiga.

38 RigBy, A., Fustice and Reconciliation After the Violence, Boulder, CO: Lynne Rienner, 2001, pp. $15-$ 30.

39 ŠEGVIĆ, S., Oružane snage EU u sigurnosnim okolnostima postmoderne ere, Split: Zbornik radova Pravnog fakulteta u Splitu, god. 47, 3/2010., pp. 621-645.

40 Holbrooke, R., Završiti rat, Šahinpašić, Sarajevo, 1998, p. 27. 
equate UN peacekeeping forces, there have been changes in US politics, ${ }^{41}$ but also in the politics of the United Kingdom. With the coming of Prime Minister Tony Blair and Foreign Minister Robin Cook, the so-called «moral foreign policy» ${ }^{42}$ was formulated, which contributed to a stronger and more determined engagement of the international community in Bosnia and Herzegovina.

Despite years of international efforts, the brutal four-year war in Bosnia and Herzegovina ended after a strong diplomatic engagement of the United States and the signing of the Dayton Peace Agreement. Although the US intervention was partly motivated by national interests ${ }^{43}$ we must not forget that the intervention of the United States in $\mathrm{BiH}$ was the largest international humanitarian intervention ever undertaken with the goal of stopping ethnic cleansing in Bosnia and Herzegovina and a few years later in Kosovo. ${ }^{44} \mathrm{We}$ will not make a mistake if we say that the American intervention in Bosnia and Herzegovina is the most important foreign policy achievement of President Bill Clinton. Europe was embarrassed by the Dayton Agreement, and on the insistence of France, the peace agreement was signed in Paris.

Although the United States played a key role in ending the brutal war, Germany, France, the United Kingdom and the European Union, in addition to the United States, are the guarantors of the Agreement and have a major role in its implementation.

41 Although in his election campaign, President Bill Clinton severely criticized George W. Bush's policies toward the war in Bosnia and Herzegovina, accusing him of being immoral because he turned his back on the most serious human rights violation in Europe after World War II, after taking over the office, Clinton continued the policy of his predecessor. Carrying the burden of the failure of US soldiers in Somalia and the crisis in Haiti, accompanied by the opposition of most of his political advisers and the US public to the intervention, President Bill Clinton did not dare to act. The change in American politics occurred only after the Republicans won the 1994 elections for the American Congress. For more information see: BuRK, J., «Public Support for peace keeping in Lebanon and Somalia: Assessing the Casualties Hypothesis,» Political Science Quarterly, 1999, pp. 53-78, and FEAVER, P.D.; GELPI, C., Choosing Your Battles: American Civil.Military Relations and the Use ofForce, Princeton, Princeton University Press, 2004.

42 Petritsch, W., Bosna i Hercegovina od Daytona do Evrope, Svjetlost, Sarajevo, 2002.

43 The US administration considered that inaction could cast a shadow on the American position of the leader of the Western world, and that Bosnian fire could spread first on Europe, and then on the USA, posing a serious threat to its national security. We also must not forget financial, economic, and energy interests. For more information, see: WORTH, R., «Clinton's Warriors The Interventionists», World Policy Yournal, Spring 1998.

44 Foreign Policy, Clinton's Foreign Policy, Carnegie Endowment for International Peace, Washington, November-December 2000 and BARDOS, G. N., Notes from the Balkans, The National Interest, The Nixon Center, Washington, Jul/Aug 2007, p. 112. 


\section{Dayton Peace Agreement and the upgrading of the EU's COMMON FOREIGN AND SECURITY POLICY}

The war in Bosnia and Herzegovina ended with the General Framework Agreement for Peace in Bosnia and Herzegovina [the Dayton Agreement], which provided the basis and created the military and political conditions necessary to end violence and build lasting peace, including establishment of political institutions and the economic recovery of the country. ${ }^{45}$ The Agreement contains 11 articles, 11 annexes, 102 maps, numerous appendices, declarations and letters. The immediate objective of the Agreement was to stop bloodshed and ethnic cleansing, and then establishing a stable multiethnic state, along with the reconciliation of the warring parties. ${ }^{46}$

The Dayton Peace Agreement was the result of the failure of European politics to treat the war in $\mathrm{BiH}$ as a strategic threat to collective security in Europe. Initially, Europe and America treated the war in Bosnia as a localized humanitarian crisis, rather than a strategic challenge to the future expansion of NATO and the European Union. ${ }^{47}$ The United States has Europeanized the Bosnian problem. At the same time, European countries had neither institutional capacities, nor the political will, and also lacked coordination mechanisms to decisively respond to, or to stop the killings, persecution, ethnic cleansing, rape and genocide in $\mathrm{BiH}$. Such a policy had far-reaching negative consequences - more than 100,000 people killed, over a million displaced persons and refugees, between 35,000 and 50,000 raped Bosniak women and girls. ${ }^{48}$ Bosnia has become a symbol of the failure of the common foreign and security policy of the European Union.

Richard Holbrooke, the creator of the Dayton Agreement, recalls that although the EU had its Special Representative, Carl Bildt, one of the three Co-Chairmen in the Dayton negotiations, Germany, Great Britain and France sent their representatives. Each of these three countries made it clear that

45 BaAs, W., The Triage of Dayton, New York, Foreign Affairs, Council on Foreign Relations, September/October 1998, pp. 32-211; and Bildt, C., Peace Fourney, The Struggle for Peace in Bosnia, London, Weidenfeld and Nicholson, 1999.

46 RigBY, A., Fustice and Reconciliation After the Violence, Boulder, CO: Lynne Rienner, 2001, pp. 15 30.

47 In the absence of a consensus on issues of crucial importance for Bosnia and Herzegovina, the same, indecisive, somewhat timid policy of the EU, unfortunately, continued in post-war years.

48 WoOdward, S. L., Balkan tragedy: chaos and dissolution after the cold war, Washington, The Brookings Institution, 1995, pp. 79-138. 
Karl Bildt did not speak on their behalf. ${ }^{49}$ According to Richard Holbrooke, the Dayton Agreement for Bosnia and Herzegovina symbolizes the strong political will, global economic and security strength, determination and commitment of the United States on one hand, and the political and institutional weakness and absence of unity of the European Union and its member states in the early 1990s, on the other. The agreement showed that the USA was still an inevitable security factor in Europe. ${ }^{50}$

«Unless the United States is prepared to put its political and military muscle behind the quest for solutions to European instability, nothing really gets done. $\gg^{51}$

Without diminishing significance of the Dayton Agreement in the context of ending the war, now I will look at the structural weaknesses and deficiencies of the Agreement, i.e. the Constitution of Bosnia and Herzegovina, so that the reader gets clearer picture about the existential challenges and problems Bosnia and Herzegovina is facing today, more than twenty years after it has been signed, on its path to building and strengthening a modern democratic society that seeks to become part of the European family. The Constitution of Bosnia and Herzegovina is an integral part of the Dayton Agreement as its Annex IV:

- The BiH Constitution gave considerable powers to its entities, Federation of Bosnia and Herzegovina and Republika Srpska, at the expense of the state, so that its entities enjoy many prerogatives of the state;

- The Dayton Agreement authorized both BiH entities to establish and develop special relations with neighbouring countries - Serbia, Montenegro and Croatia - and made it possible for the Bosnian citizens to have the citizenship of those countries; ${ }^{52}$

- The Dayton Constitution introduced the possibility of blocking the government, as well as national inequality and numerous forms of discrimination;

49 Holbrooke, R., Završiti rat, Šahinpašić, Sarajevo, 1998, p. 2.

50 Holbrooke, R., Put u Dayton, p. 373.

51 At that time-U.S. Assistant Secretary of State for European and Canadian Affairs Richard C. Holbrooke, cited in DrozdiaK, W., «Europe's Dallying Amid Crises Scares Its Critics», International Herald Tribune, February 8, 1996, p. 90.

52 Bose, S., The Bosnian State a Decade after Dayton, International Peacekeeping, Taylor \& Francis Ltd, New York, Autumn 2005, pp. 322-335. 
- The Constitution is undemocratic and, in certain provisions, it is even in complete contradiction with the European Convention on Human Rights and Freedoms;

- Bosnia and Herzegovina is practically a country with apartheid;

- Some state functions can only be performed by members of the constituent peoples - Bosniaks, Serbs and Croats - which is a direct discrimination against all non-Bosniac, non-Croats, and non-Serbs, including Jews, Roma, and members of all national minorities in $\mathrm{BiH}$;

- It enables abuse of vital national interest and veto;

- It puts too much emphasis on ethnic-national, at the expense of the civil principle;

- Dayton broke BiH's economic space and made too expensive, dysfunctional and over-decentralized state administration; ${ }^{53}$

- Bosnia and Herzegovina has the most complex state structure in the world, which is one of the most expensive ones in the world. $\mathrm{BiH}$, a small state with about 3.5 million inhabitants has two entities, Brcko District under international supervision, ten cantons, fourteen constitutions, as many governments and parliaments, an incredible 180 ministers and ministries with a corresponding vast administration; ${ }^{54}$

- $60 \%$ of gross domestic product goes on public expenditure, while $30 \%$ of GDP goes on public administration salaries;

- While in Western Europe, one official is employed to every 2000 inhabitants, this number is four times higher in $\mathrm{BiH}$, with one civil servant coming to 500 inhabitants; $;^{55}$

- Bosnia and Herzegovina is too expensive, inefficient, dysfunctional and above all complicated state at all levels of government.

The Dayton Agreement created the country practically impossible to govern. ${ }^{56}$ In this regard, it is necessary to establish a functional, rational and efficient state that will protect the rights of all its citizens, in order for the country to move along the path of economic and political development, which is a prerequisite for Bosnia and Herzegovina's entry into the European Un-

53 DuRaković, N., Domaća zadaća koju pišu stranci - Amandmani katastrofa za budućnost Bosne i Hercegovine, Oslobođenje, 06 January 2007, pp. 3-8.

54 Ibid., pp. 10-12.

55 Ibid., p. 14.

56 DaAdLer, Ivo H.; Froman, M.B.G., Dayton's Incomplete Peace, Foreign Affairs, Council on Foreign Relations, Washington, November/December 1999, pp. 218-307. 
ion and the NATO alliance. Former US Under-Secretary for Political Affairs emphasized the need to reform the Constitution of Bosnia and Herzegovina more than a decade ago, «Dayton established a state with internal divisions - the 'Berlin Wall' separating one community from the other, as it was the only way to stop the war and build insecure and fragile peace. Ten years later, these interior walls have to be demolished. The peoples of this country - Croats, Serbs and Muslims - must be allowed to integrate, as other nations in other multiethnic states do on the entire planet - such as India, the United Kingdom, and the United States. Bosnia must form new state institutions that will pave the way for a new future of the country. $>^{57}$

Dayton Agreement's creator himself, Richard Holbrooke, albeit proud of the achievements of the United States in Bosnia and Herzegovina, urged the US administration to re-engage in $\mathrm{BiH}$, this time in building a functional state. ${ }^{58}$ Stable peace, social security and economic prosperity of $\mathrm{BiH}$ citizens are needed not only for Bosnia and Herzegovina, but also for this part of the world and for the whole of Europe, so that together, as one family we can scope with global challenges, in the field of security, economics and politics as decisive, inevitable, respectable and above all united factor of global stability, peace and well-being, because the power is in unity: «Bosnia is located in the heart of Europe. Peace in Bosnia will also help build a free and stable Europe. ${ }^{59}$

\subsection{EU Treaties of Amsterdam, Nice and Lisbon}

Additional failure of the European common foreign and security policy occurred only a few years later, while the memories of the Bosnian fiasco were still alive, and in the same region just a little to the south - in Kosovo. ${ }^{60}{ }$ Once again, as earlier in the 1990s, Europeans appeared weak and incapable when responding to a security challenge in their own backyard-the Balkans.» ${ }^{61}$

57 Burns, N. R., Bosnia Ten Years Later: Successes and Challenges, US Peace Institute address, Washington D.C, 21 November 2005.

58 Holbrooke, R., «Was Bosnia worth it?», Washington Post, 19 July 2005.

59 Clinton, W. J., Letter to Congressional leaders on Bosnia, Weekly Compilation of Presidential Documents, 1996, vol 32, Issue 52, p. 2535.

60 Mahncke, A.D.; Reynolds, A., European Foreign Policy: From Rhetoric to Reality?, P.I.E.-Peter Lang, Brussels, 2004, pp. 48-98.

61 Cornish, P.; Edwards, G., Beyonf the EU/NATO Dichotomy: The Beginninings of the European Strategic Culture, 2001, vol. 77, No. 3, Changing Pattern pf European Security and Defence, Oxford University Press on behačf of the Royal Institute of International Affairs, pp. 588. 
It was the painful experience of Kosovo that urged at that time fifteen EU members to take radical steps towards consolidating a common foreign and security policy. Dissatisfaction, frustration and a sense of inferiority again due to American domination and supremacy in resolving the Kosovo crisis gathered EU member states in Helsinki into a powerful coalition that managed to achieve unprecedented consensus on institutional strengthening of its military capabilities in all its segments - combat, logistics, intelligence and communication.

«The EU agreed to develop the capacity to deploy a force of 60,000 troops by $2003 \ldots$ that would be able to carry out a range of tasks from noncombat peacekeeping, to humanitarian, rescue and combat missions; the socalled 'Petersburg tasks', which was recently incorporated into the Amsterdam Treaty on European Union (art. 17)» ${ }^{62}$

«Following the escalation of the crisis in the Balkans, and temporarily discouraged by the EU's diplomatic failures, the EU institutions reinforced the awareness that more common approach to the development of common security and defence was needed, and at the Amsterdam summit in 1997, the Treaty was concluded, which confirms the previous positions, and introduces new instruments for their realization.» ${ }^{63}$

\section{1.a. The Treaty of Amsterdam}

The Amsterdam Treaty was signed on October 2, 1997, and entered into force on May 1, 1999.64 One of the basic objectives of this agreement is to strengthen the European identity on the international scene through the implementation of a common foreign and security policy, including the progressive design of a common defence policy in the process of promoting peace, security and progress in Europe and the world. ${ }^{65}$ The objectives of

62 Ibid., pp. 589-603.

63 ŠEGVIĆ, S.; BĚLOHRADSKÝ, F., Sigurnosno-obrambena politika EU, Zbornik radova Pravnog fakulteta u Splitu, god. 45, 2/2008., p. 367.

64 Treaty of Amsterdam amending the Treaty of European Union, the Treaties establishing the European Communities and certain related acts (1997), Luxembourg: Office for Official Publications of the European Communities, available at http://www.europarl.europa.eu/topics/treaty/pdf/amst-en.pdf.

65 Treaty of Amsterdam amending the Treaty of European Union, the Treaties establishing the European Communities and certain related acts (1997), Luxembourg: Office for Official Publications of the European Communities, p. 8, available at http://www.europarl.europa.eu/topics/ treaty/pdf/amst-en.pdf.. 
the common foreign and security policy remained unchanged in relation to the Maastricht Treaty. Article J.7 of the Amsterdam Treaty also defines the tasks of the Western European Union, which include: rescue, humanitarian, peacekeeping and combat tasks in crisis situations. All EU Member States have a full right to participate in planning and making decisions regarding these activities. ${ }^{66}$

The novelty introduced by the Amsterdam Treaty in relation to Maastricht Treaty is the role of the Secretary-General of the Council, who will serve as the High Representative for the Common Foreign and Security Poli$c y$, and at the same time assist the Presidency as the primary representative of the Union in all matters in the area of foreign and security policy, primarily in drafting, preparing and implementing political decisions. ${ }^{67}$

\section{1.b. The Treaty of Nice}

The Treaty of Nice was signed on February 26, 2001, and entered into force on February 1, 2003. It established a Committee on Political and Security Issues with the task of monitoring international situation in the areas of common foreign and security policy, defining policies and monitoring the implementation of agreed policies, as well as implementing the policy of control and strategic direction of operations. ${ }^{68}$ It is only in the Declaration on European Security and Defence Policy, which forms an integral part of the Treaty of Nice, that the European Union's commitment and goal to make this policy operational as soon as possible were specified.

66 Treaty of Amsterdam amending the Treaty of European Union, the Treaties establishing the European Communities and certain related acts (1997), Luxembourg: Office for Official Publications of the European Communities, p. 13, available at http://www.europarl.europa.eu/topics/ treaty/pdf/amst-en.pdf.

67 Treaty of Amsterdam amending the Treaty of European Union, the Treaties establishing the European Communities and certain related acts (1997), Luxembourg: Office for Official Publications of the European Communities, Article J. 8, p. 14, available at http://www.europarl. europa.eu/topics/treaty/pdf/amst-en.pdf.

68 Treaty of Nice Amending the Treaty on European Union, the Treaties establishing European Cummunities and certain related acts (2001/c 80/01), Declaration on the European security and defence policy, Official Journal of the European Union, p. 8, available at https://eur-lex.europa. eu/legal-content/EN/TXT/PDF/?uri=CELEX:12001C/TXT\&from=EN. 


\section{1.c. The Treaty of Lisbon}

Signed on 13 November 2007, and came into force on 01 November 2009. The Treaty of Lisbon established the EU Foreign Affairs Council chaired by the High Representative. The foreign and security policy has been institutionalized; the powers of the High Representative have been increased to include the tasks such as to ensure the consistency of the Union's external activities, to improve external relations and to co-ordinate other aspects of the Union's external activities. Development of the Union's external action plans on the basis of the strategic guidelines of the European Council was defined as the main task of the Foreign Affairs Council. ${ }^{69}$ An external service has been established.

«The novelty in the Lisbon Treaty [the Treaty on European Union] is the establishment of the so-called permanent structured co-operation: this is a higher level of integration among member states that meet several criteria of military capabilities, in performing the most demanding missions. $\gg^{70}$

\section{INTERNATIONAL COMMUNITY AND THE IMPLEMENTATION OF THE Dayton Peace Agreement}

The responsibility of the international community to implement the Dayton Peace Agreement is one of the most important determinants of the Agreement. This responsibility is reflected in the presence of international military forces, provision of economic assistance and management of the process of reconstruction and reintegration of the country through the Office of the High Representative. ${ }^{71}$ In Dayton, a decision was made that the military and civil provisions of the agreement shall be implemented separately. The High Representative is in charge of implementing the civilian provisions of the Agreement, while military annex 1A foresees that the military provisions

69 Treaty of Lisbon, amending the Treaty on European Union and the Treaty establishing the European Community (2207/c 306/01), Officialn Journal of the European Union, p. 21, available at http://publications.europa.eu/resource/cellar/688a7a98-3110-4ffe-a6b38972d8445325.0007.01/DOC_19.

70 Rudolf, D, ml: Zajednička sigurnosna i obrambena politika europske unije..., Split, Zbornik radova Pravnog fakulteta u Splitu, god. 51, 3/2014., p. 557.

71 Pejanović, M., Međunarodna zajednica i država Bosna i Hercegovina, and Sumantra, Bose, S., The Bosnian State a Decade after Dayton, International Peacekeeping, Taylor \& Francis Ltd, New York, Autumn 2005, pp. 61-119. 
of the agreement are implemented and overseen by international troops. ${ }^{72}$ Numerous civilian agencies and international organizations, such as the OS$\mathrm{CE},{ }^{73}$ the UNHCR, the World Bank and the IMF, have been involved in the implementation of the Dayton Agreement.

The negotiation process that resulted in the signing of the Dayton Agreement was led by the United States, while the implementation of its civilian provisions was left to the Europeans. Namely, it was agreed in Dayton that the High Representative would always be a European, one deputy German, and the other American. ${ }^{74}$ Functions of the High Representative - the highest international civilian authority in $\mathrm{BiH}$ - were initially extremely limited. ${ }^{75}$ However, two years after the signing of the Dayton Agreement, the High Representative was given increased, the so-called «Bonn Powers», ${ }^{76}$ which enabled the High Representative to replace officials who obstruct the implementation of the Agreement, and imposed the adoption of laws, when local authorities are not willing to do so. ${ }^{77}$

All the key laws regulating establishing or functioning of the central state institutions such as the Court of Bosnia and Herzegovina, Prosecutor's Office of Bosnia and Herzegovina, High Judicial and Prosecutorial Council, Central Bank, Intelligence and Security Agency, Indirect Taxation Administration have been «imposed» by the High Representative before being adopted in a regular parliamentary procedure in the Parliamentary Assembly of BiH. We should not

72 Caplan, R., Assessing the Dayton Accord: The Structural Weaknesses of the General Framework Agreement for Peace in Bosnia and Herzegovina, Diplomacy \& Statecraft, Published by Frank Cass, London, July 2000, pp. 213-232

73 Talbott, S., The OSCE in Bosnia, U.S. Department of State Dispatch, 11 December 1995, vol. 6, Issue pp. 50-52, Speech.

74 Chandler, D., From Dayton to Europe, International Peacekeeping, Taylor \& Francis Ltd, New York, Autumn 2005, pp. 336-349.

75 CaPLan, R., International Authority and State Building: The Case of Bosnia and Herzegovina, Global Governance, Lynne Reinner Publishers, 2004, pp. 53-65.

76 At the meeting of the Peace Implementation Council, the body tasked with overseeing the implementation of the Dayton Agreement, composed of all states and organizations involved in the implementation of the Agreement, held in Bonn in 1997, it was decided to give the High Representative in Bosnia and Herzegovina the powers that would facilitate the process of making binding decisions, and enable removal of all political representatives who obstruct the implementation of the Dayton Agreement. In the beginning, the High Representative used these powers extensivelly, however, in recent years, unfortunately, he completely refrains from using them, directly contributing to the maintenance of the painful political status quo.

77 CaPLAN, R., International Authority and State Building: The Case of Bosnia and Herzegovina, Global Governance, Lynne Reinner Publishers 2004, pp. 53-65. 
neglect the importance of the international community when it comes to the return of refugees and displaced persons, protection of human rights, and economic reconstruction of Bosnia and Herzegovina. ${ }^{78}$ These are just some of the examples of the international community's efforts in Bosnia and Herzegovina, which was crucial for the building of democracy, democratic society and democratic institutions in Bosnia and Herzegovina, as well as for reform processes that involve the adoption and application of international standards. ${ }^{79}$

In the post-war period, Bosnia and Herzegovina was largely built, the infrastructure was restored and the overall situation normalized. «Peace has been achieved and there is a clear sense of increased security throughout the country. $\gg^{80}$ In 2000, the European Stability Initiative announced that although uneven, efforts in reconstruction were «extremely successful». ${ }^{81}$ The post-conflict reconstruction plan in Bosnia and Herzegovina has been a significant success. Since the end of 1995, the international community has donated around \$ 9 billion in reconstruction assistance, ${ }^{82}$ «about $\$ 1,200$ per person has been provided for the reconstruction of the country or about nine times more than within the Marshall Plan.» ${ }^{83}$ The biggest donors were the European Union, the World Bank and the US Government. Paradoxically, the country has not managed to achieve economic recovery.

\subsection{Implementation of the military provisions of the Agreement}

On December 20, 1995, the then UN Secretary General Boutros Ghali announced the end of the existence of UNPROFOR and announced the formation of multinational forces (IFOR). These forces, which replaced 20,000

78 Ducasse-Rogier, M., «Recovering from Dayton: From 'peace-building' to 'state-building' in Bosnia and Herzegovina», Helsinki Monitor, 2004, pp. 91-153.

79 Curtiss, R.H., Bosnia Ten Years Later, Washington Report on Middle East Affairs, Washington, Sep/Oct 2005, pp. 44-45, Report.

80 BILDT, C., «A Second Chance in the Balkans», Foreign Affairs, 80 January/February 2001, pp. 148-158; Ivo H. Daalder and Michael B.G. Froman, Dayton's Incomplete Peace, Foreign Affairs Council on Foreign Relations, Washington, November/December 1999, pp. 106-113.

81 Reshaping International Priorities in Bosnia and Herzegovina, mart 2001, European Stability Initiative http://www.esiweb.org, 19 April 2002.

82 Bosnia's Precarious Economy: Still Not Open for Business, International Crisis Group, Balkans Report, No. 115, 07 August 2001.

83 BeLloni, R., «Civil Society and Peace Building in Bosnia and Herzegovina», Fournal of Peace Research, International Peace Research Institute, Oslo, March 2001, pp. 163-180. 
UNPROFOR forces, were in charge of the implementation of the military provisions of the Dayton Agreement and numbered 60,000 troops comprised of NATO member states and third countries. ${ }^{84}$ The one-year IFOR mission began in December 1995. This was entirely a NATO mission, elaborated in Brussels outisde the UN scope..$^{85}$ What is especially important when it comes to IFOR mission is that the officers of non-NATO countries were incorporated in the command structure of the IFOR force under the command of the NATO Council, although the Americans held key commanding positions. ${ }^{86}$

In addition, the involvement of the NATO forces in Bosnia and Herzegovina within the framework of the IFOR mission was in many ways unique. ${ }^{87}$ Namely, it was the first operation outside the NATO area with the partners of the member states of the Partnership for Peace ${ }^{88}$ and non-NATO member

84 Petritsch, W., Bosna i Hercegovina od Daytona do Evrope, Svjetlost, Sarajevo, 2002, p. 67.

85 Christopher, W., «NATO: Reaching out to new partners and new challenges», U.S. Department of State Dispatch; 11 December 1995, vol. 6, Issue 50-52, p. 902, Speech.

86 LEURDIJK, D.A., «Before and after Dayton: the UN and NATO in the former Yugoslavia», The World Quarterly, Taylor and Francis Group, London, 1997, pp. 457-470.

87 After erecting the iron curtain and dividing the world into the Eastern and Western blocs in 1949, the Western countries formed the NATO alliance as a collective defense system and a clear response to the security threats posed by the Soviet Union and the East Bolsheviks. Its primary mission, defined in Article 51 of the UN Charter and Article 5 of the Washington Treaty, was the protection and preservation of the freedom and security of its member states, the prevention of the outbreak of war and the prevention of the spread of communism. With the collapse of the Soviet Union and the Warsaw Pact and the establishment of the new security architecture, someone would have thought that the reason for the existence of the NATO alliance disappeared. By the end of the Cold War, the concept of security has been drastically changed so that, in addition to defending, it also includes an economic and political component. Keeping up with the modern security development, NATO planners have decided that its next mission would be protection of human rights and the advancement of democracy. In the spring of 1999, NATO deeply deviated from its original mission in Kosovo for the first time in an offensive, rather than defensive style. September 11 further modified NATO mission formally introducing the concept of self-defense. For more information see: GABOR, F.A., «Reflections on NATO's New Mission: Conflict Prevention in the Struggles for Ethnic Self-Determinaion», Review of Central and East European Law 2004, pp. 247-256, 2004, Koninklijke Brill N.V., Printed in the Netherlands, and McLaughlin, J. C., US-Russian cooperation in IFOR: Partners for peace, Military Review, Fort Belvoir VA, juli/avgust 1997, pp. 42-88.

88 In implementing military provisions of the Dayton Agreement, NATO under the control and domination of the United States, gathered a coalition of countries that was truly unprecedented. In addition to numerous countries from Europe and North America, Russian troops had significant role in the IFOR forces, and later on in SFOR. For the first time since the end of the Cold War two major cold-war enemies - the United States and Russia - took part in the same joint task on a partnership basis under the joint command. This was a unique and, at the same time, a successful mission, one positive experience in a very difficult post-war circumstances. For more information see: VOBLENKO, V.V., Multinational Peacekeeping Operations in the Balkans: Past and Present, Military Thought. 
states, under a joint command and in accordance with NATO rules. ${ }^{89}$ In addition to military tasks, the mandate of IFOR included establishing an environment for the uninterrupted implementation of the civilian provisions of the agreement, providing support to the International Criminal Tribunal for the former Yugoslavia, as well as ensuring freedom of movement.

The Stabilization Force - SFOR were formed by the Resolution 1088 of the UN Security Council after the successful completion of the IFOR mission, on 12 December 1996. In addition to continuing the IFOR mission, SFOR's tasks were to ensure lasting peace in Bosnia and Herzegovina and to provide support to civilian agencies working on the implementation of the Agreement. ${ }^{90} 36,000$ SFOR troops ${ }^{91}$ from 37 countries members and non-members of NATO from all over the world were deployed in three multinational divisions: the Multinational Division Northeast, mainly composed of French forces and under the command of the French General, the Multinational Division Southwest largely filled by forces from Great Britain and led by the British General and the Multinational Division North, mainly comprised of US soldiers led by the US General. ${ }^{22}$

In accordance with UN Security Council Resolution 1575 of 22 November 2004, NATO has completed operations under the Stabilization Force (SFOR). ${ }^{93}$ At the Istanbul Summit, NATO members «agreed to conclude the Alliance's successful SFOR operation in Bosnia and Herzegovina and welcomed the readiness of the European Union to deploy a new and distinct UN-mandated Chapter VII mission in the country, based on Berlin-plus arrangements agreed between our two organizations.» ${ }^{94}$ However, NATO did

89 Albrigth, M., A New NATO for a new century, Dispatch, 10(3), 1999, p. 7.

90 CirafiCI, J.L., SFOR in Bosnia in 1997: A watershed year, US Army War College, Carlisle, 1999, pp. 208-252.

91 As the situation on the ground stabilized, SFOR's structure changed and the number of troops decreased. With an initial 60,000 members of the IFOR force, over 36,000 initial SFOR troops, in December 2003, this force numbered 7,000 soldiers. Multinational brigades have also been transformed into multinational forces. For more information see: Generalmajor Virgil Packett, James F. Smith, Edwin P. Woods and Edward C. Guilford, Bosnia and Herzegovina: Coalition Doctrine and LOT Houses, Military Review, Fort Belvoir VA, March-April 2005.

92 Clinton, W.L., Letter to Congressional leaders on Bosnia, Weekly Compilation of Presidential Documents, 1996, vol 32, Issue 52, p. 535.

93 KrIENDleR, J., NATO Crisis Management Cooperation with PfP Partners and Other International Organizations, Partnership for Peace Consortium of Defence Academies and Security Studies Institutes, vol. 3, No. 4, December 2004, p. 66.

94 «Istanbul Summit Communiqué.» Quoted in John Kriendler, NATO Crisis Management Cooperation with PfP Partners and Other International Organizations, Partnership for Peace Consortium of Defence Academies and Security Studies Institutes, vol. 3, No. 4, December 2004, p. 67. 
not end its engagement in Bosnia and Herzegovina. ${ }^{95}$ Namely, NATO formed the Staff in Sarajevo, which initially numbered 7,000 ${ }^{96}$ soldiers and which, together with the EUFOR, became the legal successor to SFOR. ${ }^{97}$ In addition to the tasks undertaken so far by the troops in charge of the implementation of the military provisions of the Dayton Agreement, the NATO Staff and EUFOR missions have been expanded to include defence reform and anti-terrorism activities. ${ }^{98}$

Apart from this, the first civil emergency assistance operation in the framework of the European Security and Defence Policy was launched on January 1, 2003. An EU Police Mission (EUPM) was formed, which replaced the UN International Police Task Force in BiH (IPTF). The EUPM was the first civilian crisis control operation under the European Security and Defence Policy (ESDP). EUPM members came from 33 countries, at the time 27 EU Member States, as well as Iceland, Canada, Norway, Sweden, Turkey and Ukraine. ${ }^{99}$ The mission did not have executive powers, which confirmed the increased responsibility of $\mathrm{BiH}$ and the reduction of the role of the international community. Its main mission was establishing professional, sustainable and multi-ethnic police force that works in accordance with the best European and international standards. In addition, EUPM has supported the process of reforming local police forces, developing and consolidating local police capacities and regional cooperation in the fight against organized crime. The mandate of EUPM ended on December 31, 2011. ${ }^{100}$

During the implementation of the Dayton Agreement, which began after the signing of the Agreement and continues to date, the European Union's forces, together with the US forces, with their military presence in Bosnia and Herzegovina, were the guarantors of the peace and security in BiH. ${ }^{101}$

95 Kampschror, B., «NATO exits Bosnia», Cbristian Science Monitor, 03 December.2004, p. 83.

96 NATOStaff today has only 65 staff members, 21 military and 44 civilian, https://jfcnaples.nato. int/hqsarajevo/about-sarajevo-/nhqsa-team.

97 Rodman, P.W, «Yalta in the Balkans», National Review, 1995, p. 66.

98 JosEPH, E.P., Back to the Balkans, Foreign Affairs, Council on Foreign Relations, New York, Jan/ Feb 2005, pp. 111-122

99 EUPM documents, Direction for European Integrations BiH, available at http://www.dei.gov. $\mathrm{ba} /$ dokumenti/default.aspx? id=4593\&langTag=bs-BA.

${ }^{100}$ EUPM Mission desription, European External Action Service, https://eeas.europa.eu/archives/ csdp/missions-and-operations/eupm-bih/index_en.htm.

${ }^{101}$ SJURSEN, H., On the Identity of NATO, International Affairs, 80(4), 2004, p. 702. 


\section{EU COMMON SECURITY AND DEFENCE POLICY}

The European Defence Community Treaty was the first step in establishing common European defence policy. The Treaty was signed on May 27, 1952 in Paris, and the signatory countries were France, Germany, Italy, Belgium, the Netherlands and Luxembourg. Unfortunately, the Treaty remained only a dead letter since it did not pass the ratification in the French Parliament. ${ }^{102}$ The next attempt at a stronger European unification in the field of defence and security took place two years later, with the establishment of the Western European Union, which, although more successful than the former, still did not get full momentum. «Regardless of the initial upswing, NATO obscured all the intentions of the WEU founders by leaving them insignificant and routine jobs.» ${ }^{103}$

Unwilling to renounce their sovereignty in the field of security on the one hand, and yet insufficiently strong in military terms to resist the constant attempts of one of the two superpowers, the Soviet Union in spreading power and influence on the other, European countries have decided to rely on the United States and NATO as a credible and powerful military force, while continuing to lead individual policies in the field of defence and security. A more serious approach to the establishment of a common European security and defence policy was taken after a series of tectonic geopolitical changes such as the fall of the Berlin Wall, the collapse of the Soviet Union, the end of the Cold War, and the emergence of the United States as the only truly global superpower, or the establishment of a unipolar world order. ${ }^{104}$

After a series of unsuccessful attempts, common foreign and security policy was first defined by the Maastricht Treaty in 1992. Article J.4 of the Treaty specifies that the Western European Union, as an integral part of the development of the Union, will elaborate and implement decisions and activities of the Union that have defence implications, while stating that the obligations of the member states within the NATO will be respected and that all activities

102 Mahncke, A.D.; Reynolds, A., European Foreign Policy: From Rhetoric to Reality?, P.I.E.-Peter Lang, Brussels, 2004, pp. 48-98.

103 ŠEGVIĆ, S., Frano Belohradsky: Sigurnosno-obrambena politika EU, Zbornik radova Pravnog fakulteta u Splitu, god. 45, 2/2008., p. 344.

104 Volker, P.; MaIR, S. (eds.), European Foreign and Security Policy: Challenges and Opportunities for the German EU Presidency, Research paper 2006/RP10, Berlin: German Institute for International and Security Affairs (SWP), October 2006, pp. 18-66. 
of the Union in defence areas to be compatible with the common security and defence policy established within NATO. ${ }^{105}$

In the Declaration of Belgium, Germany, Spain, France, Italy, Luxembourg, Portugal and the United Kingdom on the role of the Western European Union and its relationship with the European Union and the North Atlantic Treaty, which is an integral part of the Maastricht Treaty, the member states of WEU recognized the need to truly strengthen the European security and defensive identity and greater European responsibility in defence matters. The WEU member states have agreed to strengthen its role as the defensive component of the European Union, within the long-term perspective of the EU's common defence policy. In order to fulfil this goal, it will formulate a common European defence policy, and work on its implementation through the further development of its operational role. At the same time, WEU will develop cooperation and partnership with the North Atlantic Treaty Organization in matters of common interest. ${ }^{106}$

Although political cooperation between the European Union countries began in 1970, which served as platform for discussion about security and foreign policy issues, the Maastricht Treaty institutionalized and marked a whole new chapter in the development of the common foreign and security policy. On the other hand, common European and security policy experienced its full momentum after the meeting of the European Council in Cologne held in June 1999. ${ }^{107}$ The Nice Treaty gave a formal status to the new EU Military Committee, ${ }^{108}$ and at the NATO summit held in Prague, a decision was made to establish a Rapid Response Force (RRF). ${ }^{109}$

«The circumstances in which the EU found itself at the end of the last century have led the EU to precisely articulate its objectives, institutions

\footnotetext{
105 Council of the European Communities (1992), Treaty on European Union, Luxembourg: Office for Official Publications of the European Communities, p 128, available at https://europa. eu/european-union/sites/europaeu/files/docs/body/treaty_on_european_union_en.pdf.

106 Council of the European Communities (1992), Treaty on European Union, Luxembourg: Office for Official Publications of the European Communities, Declaration by Belgium, Germany, Spain, France, Italy, Luxembourg, the Netherlands, Portugal and the United Kingdom of Great Brltain and Northern Ireland, which are members of the Western European Union and also members of the European union on the role of the Western European Union and its relations with the European Union and with the Atlantic Alliance, pp. 244-247.

107 Crowe, B., A Common European Foreign Policy after Iraq, Oxford University Press on behalf of the Royal Institute of International Affairs, vol. 79, No.3, May 2003, p. 533.

108 Ibid., p. 534.

${ }^{109}$ Ibid., p. 540.
} 
and instruments of its foreign policy within the integration processes, with the need to create and develop the EU's military capacities to become one of the most important political issues of the Union.»110

Efforts to establish a joint European defence structure and its own security identity lasted until the end of the last century. Only in the beginning of the new millennium, more precisely in 2003, the EU, for the first time since its decades-long existence, adopted its own strategic document in the field of security - the European Security Strategy.

Despite all the efforts that the European Union has been investing in the field of defence and security, it is still «an economic giant, a political dwarf and a military worm.» ${ }^{111}$ That in no way does not mean that the EU does not have significant military force. Most of the EU member states are at the same time NATO members armed with state-of-the-art military technology, and some are also nuclear powers. ${ }^{112}$ Additionally, some of the member countries are also the world's largest arms exporters. ${ }^{113}$

To what extent is the European Union likely to achieve greater cohesion in the future when it comes to common security policy? What does for Europe mean NATO membership under the US command. For almost seven decades,

110 ŠEGVIĆ, S., Oružane snage EU u sigurnosnim okolnostima postmoderne ere, Split: Zbornik radova Pravnog fakulteta u Splitu, 47, 3/2010., p. 623.

111 The phrase «economic giant and political dwarf» was used about Germany and Japan after the Second World War. Quoted in Jorge Silva Paulo, The European Defense Sector and EU Integration, Partnership for Peace Consortium of Defence Academies and Security Studies Institutes, vol. 8, No. 1, Winter 2008, p. 13.

112 Gordon, N. i Pardo, S., «What Can Pro-Democracy Activists in Arab Countries Expect from the European Union? Lessons from the Union's Relations with Israel», U: BAUER, P. (ur.). Arab Spring Challenges for Democracy and Security in the Mediterranean, London i New York, Routledge, 2015, pp. 100-119. LongO, F., «The Relevance of Security Sector Reform in Humanitarian Intervention: The Case of the European Union in the Mediterranean», U: BAUER, P. (ur.), Arab Spring Challenges for Democracy and Security in the Mediterranean, London i New York: Routledge, 2015, pp. 177-192.

${ }^{113}$ France and the United Kingdom, along with China, the United States and Russia, belong to the group of the world's largest arms exporters. These five countries are also permanent members of the Security Council, the body whose primary task is the preservation of world peace and security. The irony is that the countries with the greatest political influence in this global security body are at the same time most responsible for the arming of various warring parties around the world, as these five countries account for $70 \%$ of total global arms export. France and Great Britain are also nuclear powers, along with the United States, Russia, China, India, Pakistan, Israel and North Korea. For more information, see: Peter Hough, Shahin Malik, Andrew Moran, and Bruce Pilbeam, International Security Studies, Theory and Practice, Routledge Taylor \& Francis Group, London and New York, 2015, pp. 119-150. 
NATO has been in charge of security in Europe. NATO is too strong in organizational, institutional, and infrastructural sense; consequently it adapted quickly to the new geopolitical circumstances and, leaving its NATO area, ${ }^{114}$ has found a new mission, which includes peacekeeping operations, the fight against terrorism and the proliferation of weapons of mass destruction. ${ }^{115}$ The security situation and the modern warfare have changed to a large extent in relation to the mid-1990s. Although it lost its original mission, NATO has not lost importance. ${ }^{116}$ «NATO remains vital in ensuring European security and stability: not only because it is a tried and tested forum for discussion, including with non-European allies, security and defence issues, but also because of the essential transatlantic military links embodied in NATO's integrated military structure..$^{117}$

However, NATO is not only important in the field of security and defence. By acting as a powerful alliance with a modified mission, adapted to modern security challenges, NATO also provides significant support to European political processes. Perhaps the reason lies in the fact that the goal of the EU's common security and defence policy is not to secure the defence of the EU member states in the sense it has been provided by NATO, but to carry out the so-called «Petersbursg tasks»- humanitarian, rescue and peacekeeping tasks. ${ }^{118}$ By enhancing its military capacity, the European Union can contribute to the establishment of a balanced transatlantic partnership that will be the backbone of global security. ${ }^{119}$ Although some authors believe that NATO and the United States will continue to dominate Europe's security landscape in the future «The USA will still be dominant in the European security policy and in this respect one might even say the most

\footnotetext{
${ }^{114}$ Senator LUGAR, R.G., «NATO: Out of Area or Out of Business. A Call for U.S. Leadership to Revive and Redefine the Alliance», Speech at the Overseas Writer's Club, Washington D.C., 24 June 1993.

115 DE Dardel, J.-J., Outreach Strategies in the wake of NATO and EU enlargement Refocusing on the Partnership fo Peace, Partnership for Peace Consortium of Defence Academies and Security Studies Institutes, vol. 3, No. 2, June 2004, p. 101.

${ }^{116}$ SJuRSEN, H., On the Identity of NATO, International Affairs, 80(4), 2004, p. 34.

117 David Heathcoat-Amory explains in greater detail European security issues and the development of the WEU in his article in the fuly I994 issue of The World Today quoted in Douglas Hurd, Developing the Common Foreign and Security Policy, International Affairs, Oxford University Press on behalf of the Royal Institute of International Affairs, vol. 70. No 3. July 1994, pp. 421-428.

118 Yost, D.S., Transatlantic Relations and Peace in Europe, Oxford University Press on behalf of the Royal Institute of International Affairs, vol. 78, No. 2, April 2002, p. 292.

${ }^{119}$ Ibid., pp. 277-278.
} 
prominent EU member.» ${ }^{120}$ After all, «In Bosnia and Kosovo, NATO has been a major actor through IFOR/SFOR and KFOR in providing security under a mandate of the UN Security Council.» ${ }^{121}$

Since the end of the Second World War, the American troops or NATO, being present on the European soil, have protected their European allies and prevented the spread of Soviet influence, both from the outside and from the inside. ${ }^{122}$ Throughout the Cold War Europe enjoyed strong American protection to such an extent that we could say that it was under some kind of security protectorate. Even today, after the end of the Cold War, and the collapse of the Soviet Union, and numerous security initiatives, NATO continues to be the backbone of Europe's security. ${ }^{123}$

NATO is still fundamental for stability and peace on this continent, ${ }^{124}$ and at the same time it is the most respectable and the most powerful security alliance in the world, with a number of countries still strongly endeavour to become its member, including Bosnia and Herzegovina.

\subsection{Bosnia and Herzegovina and membership in NATO and the European Union}

With the adoption of the Law on Defence Reform which established unified army under the command and control of state institutions, and with the accession to the Partnership for Peace Program, ${ }^{125}$ on December 14, 2006, Bosnia and Herzegovina made a historical step towards Euro-Atlantic integration. Ten years after the end of the brutal war, the once-warring parties,

${ }^{120}$ CobelEns, P., 'De NAVO vergelijkenderwijs', Militaire Spectator, April I999, pp. 198-205 (in Dutch). The translation of this passage is by Colonel Cobel quoted in YOST, D.S., Transatlantic Relations and Peace in Europe, Oxford University Press on behalf of the Royal Institute of International Affairs, vol. 78, No. 2, April 2002, p. 296.

${ }^{121}$ De Dardel, J.-J., Outreach Strategies in the wake of NATO and EU enlargement Refocusing on the Partnership fo Peace, Partnership for Peace Consortium of Defence Academies and Security Studies Institutes, vol. 3, No. 2, June 2004, p. 100.

122 HARVEY, F.P., «Addicted to security», International fournal, 59(1), 2003-4, p. 16.

${ }^{123}$ BRZEZINSKI, Z., AMERIČKI IZBOR: Globalna dominacija ili globalno vodstvo, Politička kultura, nakladno-istraživački zavod, Zagreb, 2004, CID Podgorica, 2004.

${ }^{124}$ Christopher, W., «NATO: Reaching out to new partners and new challenges», U.S. Department of State Dispatch; 11.12.1995, vol. 6, Issue 50-52, p. 902, Speech.

125 The Partnership for Peace program is a NATO initiative launched in 1994 to extend defense cooperation to the countries of Central and Eastern Europe and represents the first level of institutional dialogue with the Alliance, but does not guarantee admission. 
with strong support of the United States, formed a joint military force compatible with NATO. Taking these and other steps, Bosnia and Herzegovina has demonstrated its strong commitment to NATO membership. ${ }^{126}$

Whatever irresponsible $\mathrm{BiH}$ political leadership might me, it is nevertheless aware that the future of Bosnia and Herzegovina is full integration into European and Euro-Atlantic institutions - European Union and NATO. This is, at the same time, the main foreign-policy priority of the state. ${ }^{127}$ Future NATO membership is essential for security and overall prosperity of BiH citizens - political, economic and social. There are numerous economic advantages that will come with a normal trade relationship with the United States and Europe, as well as the political and security benefits that come with membership in NATO and the European Union, which $\mathrm{BiH}$ needs and must take advantage of. Bosnia and Herzegovina can do this only if it becomes a member of the European Union and the NATO. ${ }^{128}$ Bosnia and Herzegovina should at any cost join the NATO for the following reasons:

- Any possibility of war and international conflict in $\mathrm{BiH}$ would be avoided;

- Danger of any kind of external intervention on Bosnia and Herzegovina would be eliminated;

- The poor BiH economy would considerably be relieved of the expenditure for military and defence;

- It would significantly improve political and legal security of $\mathrm{BiH}$, which would pave the way for foreign and domestic investments, i.e. attracting capital. Capital goes where legal, political and military security is, and this is all achieved by joining NATO.

NATO membership must be the future of this region, because the rest of Europe enjoys security, prosperity and peace. Now is the time for people from Bosnia and Herzegovina to be given the same opportunity. ${ }^{129}$

Finally, it should be emphasized that joining the NATO would greatly accelerate the process of Bosnia and Herzegovina's admission to the European

126 KovačEvić, D., «Bosnia’s Eleventh Hour Defense Reform», Transitions Online, 12 August 2003.

127 PowELL, C.L., «Press statement during the visiti to Sarajevo 31 July 2004», retrieved from the State Departmenta web site, http://www.state.gov/.

128 General Sir Rupert Smith, Deputy Commander of Allied Forces in Europe, 1998-2002, interview with Patrice McMahon u Boca Raton, Florida, 22 February 2002.

129 FenENKO, A., «Voronzeh državni Univerzitet», Balkan Factor and European Security, International Affairs, Blackwell Publishing, Chatham House, London, 2002, pp. 70-99. 
Union and other Euro-Atlantic institutions. Namely, by fulfilling the conditions for full membership in the European Union, i.e. by fully introducing European standards and norms in all spheres of social, political, and economic life, Bosnia and Herzegovina would achieve internal stability and conduct the necessary democratization of institutions and the entire society. In other words, becoming member of the European Union would remove all obstacles that prevent normal functioning of the state. In addition, harmonization of national legislation with the acquis communautaire would enable the building of democratic and market institutions and the establishment of direct business relations with companies in European countries.

European Union membership, at the same time means entering the largest single market in the world, with free movement of goods, labour, capital, services and knowledge, without fiscal, customs and other barriers. Entering the vast European financial market would open up significant investment opportunities, the development of agriculture, while small and medium-sized businesses would experience full momentum, and the state would connect with the transport and telecommunications European network, which would significantly reduce the unemployment rate in Bosnia and Herzegovina.

Advantages of joining the family of European countries include access to economic, scientific, research, educational, cultural and other projects and programs. It would also pave the way for co-operation between universities and the economy, which would enable acquiring practical knowledge and experiences in order to improve the competitiveness of $\mathrm{BiH}$ young people. By joining the $\mathrm{EU}$, the fight against all forms of the most serious and organized international crime would be made much easier, and also enhance Bosnia's own internal security, contributing to the collective security of the European Union.

As before the war, Bosnia and Herzegovina was the demographic microcosm of what Yugoslavia had been and could, in a way, be the pillar of such a renewed regionalism in much of the former Yugoslav space.

\section{BOSNIA AND HERZEgOVINA'S BRUSSELS PHASE}

The future of Bosnia and Herzegovina is certainly in the European Union. Admission to the Council of Europe in early 2002 for Bosnia and Herzegovina was the first step towards institutional integration into Europe. During the European Union summit in Zagreb in October 2000, the role of further development of Bosnia and Herzegovina was given to the European Union. 
After joining the Council of Europe and starting the realization of the Road Map of the European Union, it seems that in $2002 \mathrm{BiH}$ firmly set off its journey from Dayton to Europe. ${ }^{130}$

The Brussels phase marks the completion of the transition process from crisis management and stabilization to the process of building and strengthening the state of Bosnia and Herzegovina and its central institutions. Brussels symbolizes the return and increasingly important presence of Europe in Bosnia and Herzegovina and the region and the end of US hard diplomacy. Namely, the Dayton phase of Bosnia and Herzegovina was characterized by the strong engagement of the United States and the frequent visits by its high officials, both civilian and military. On the other hand, the Brussels phase is characterized by little or no US interest in Bosnia and Herzegovina, and the completion of the initial reform processes started after the signing of the Dayton Agreement and an increasingly active engagement, both political and financial, of the European Union in Bosnia and Herzegovina. ${ }^{131}$

130 The institutional relationship between Bosnia and Herzegovina and the European Union began soon after the signing of the Dayton Agreement, in 1997 to be more precise, when the EU Council of Ministers set up political and economic conditions for the development of bilateral relations. In March 2000, BiH received 18 conditions to be met in order to start negotiations on a Stabilization and Association Agreement (SAA) within the Roadmap. Along the way to concluding a Stabilization and Association Agreement, BiH had to answer 346 questions from the European Commission in the field of politics, economics and other relevant areas. The agreement was signed in June 2008. In December 2002, pursuant to the Council of the European Union Regulation 2666/2000, the CARDS EU Technical Assistance Program for Reconstruction, Development and Stabilization was launched. The Council of the European Union adopted the first European Partnership with Bosnia and Herzegovina in March 2004, and in January 2007 the IPA Instrument for Pre-Accession Assistance was established. Since 2011, the structural dialogues between the European Union and $\mathrm{BiH}$ have begun in the field of politics and economics. In July 2015, a Reform Agenda was adopted aimed at solving the difficult socio-economic situation and improving the rule of law and public administration reform. A formal application for BiH membership in the European Union was submitted on 15 February 2016. In December of the same year, BiH received the questionnaire from the European Commission. In February this year, BiH submitted answers to the European Commission's questionnaire. The European Union is institutionally present today in Bosnia and Herzegovina through the Delegation of the European Union to Bosnia and Herzegovina, headed by the Special Representative. For more information, see the European Commission, Report on Bosnia and Herzegovina for 2016, Communication from the Commission to the European Parliament, the Council, the European Economic and Social Committee and the Committee of the Regions, EU Enlargement Policy Release 2016, Brussels, 09 November 2016. http://dei.gov.ba/dei/media_servis/vijesti/default. aspx?id=17696\&langTag=bs-BA and Chronology of BiH-EU Relations, Directorate for European Integration $\mathrm{BiH}$, http://dei.gov.ba/dei/bih_eu/default.aspx? id = 9808 \& langTag = bs-BA.

131 Chandler, D., From Dayton to Europe, International Peacekeeping, Taylor \& Francis Ltd, New York, Autumn 2005, pp. 167-181. 
In the past twenty years, international community has done a very important job in Bosnia and Herzegovina. ${ }^{132}$ There has been significant progress in building state and society, progress made by the international community, but also by the country's citizens. The physical and post-conflict reconstruction of the country was successful. Most of the laws adopted in the Parliamentary Assembly of $\mathrm{BiH}$ are in the function of approaching Brussels. Of the three state ministries that $\mathrm{BiH}$ had in 1997, there are now nine, as well as dozens of different state agencies. ${ }^{133}$

However, we are still facing the burning problem of unemployment, corruption, organized crime and the lack of future prospect for young people. The implementation of international strategies is slow and complicated by various factors. Under conditions of ambiguity characterized by the Dayton Agreement, complex institutional structures, a huge administrative apparatus, and too many levels of government, the implementation of vital reforms proved to be particularly complex. ${ }^{134}$

I have repeatedly pointed out that for Bosnia and Herzegovina to conduct the necessary reforms it would need a renewed commitment from the international community. Unfortunately, I believe that the European Union itself will not be able to end the reform processes in Bosnia and Herzegovina and make $\mathrm{BiH}$ truly modern, democratic and stable society. This is simply because of the fact that the removal of the structural deficiencies of the Dayton Agreement that prevent establishment of a functional and economicaly strong society and state cannot be carried out without its creator - the United States. Therefore, I believe that a strong and determined transatlantic partnership will be needed again as well as commitment to finish the process of making European Union a whole.

The ultimate goal of $\mathrm{BiH}$ is to become part of an exclusive club of European countries. The war in Bosnia and Herzegovina has prompted the EU member states to rethink their common foreign and security policies and find new mechanisms to consolidate and strengthen these policies. Recognizing it or not, whether aware of it or not, the success of a united Europe will large-

132 McMahon, P.C., «Rebuilding Bosnia: A Model to Emulate or to Avoid?», Political Science Quarterly, The Academy of Political Science, New York, 2004-05, pp. 7-36.

133 IbRAHIMAgIĆ, O., Bosna i Bošnjaci poslije Dejtona, Vijeće kongresa bošnjačkih intelektualaca, Sarajevo, 2000, pp. 25-271.

${ }^{134}$ KAMPSCHROR, B., «Though Bosnia's war is long over, battle lines remain clearly...», USA Today, 11 July 2005, p. 39. 
ly depend on the success of a strong, democratic and integrated Bosnia and Herzegovina. Bosnia and Herzegovina is an inseparable part of Europe, geographically and historically, its past, present and future. Overcoming all the challenges facing the European Union today will go alongside the elimination of all obstacles to the normal functioning of the state of Bosnia and Herzegovina.

\subsection{The New Millennium U.S. Foreign Policy towards Bosnia and Herzegovina}

The relationship between the United States and $\mathrm{BiH}$ towards the end of the 1990s was a characterized by serious U.S. military and diplomatic efforts - ending the war, preventing humanitarian catastrophe, signing the Dayton Agreement, establishing and maintaining peace, and building the state. ${ }^{135}$ The president himself and the first State Department echelons were constantly engaged in $\mathrm{BiH}$. Bosnia and Herzegovina is the most important foreign policy achievement of the Bill Clinton administration, which is still being praised by US democrats. A small country with 3,500,000 people in the southeast of Europe has become a foreign policy priority of the United States. So it was until the beginning of the new millennium. ${ }^{136}$

However, September 11 changed everything. US foreign policy priorities have been radically modified, and in those priorities there was no place for Bosnia and Herzegovina. In the years after $9 / 11$, the absence of any serious, institutional interest of the United States in Bosnia and Herzegovina is evident. The only issue in which $\mathrm{BiH}$ is interesting for America is the fight against terrorism. ${ }^{137}$ Over the past two decades, the United States has been

135 KoKTA, R. M., Sharing Risks, Burdens and Benefits: American Foreign Policy in the Balkans in the 1990s, Southeast European and Black Sea Studies, Published by Frank Cass, London, maj 2003, p. 186.

${ }^{136}$ Hromić, H., Pregled vanjske politike SAD, Srednjoročni izgledi za zapadni Balkan: Konsolidacija sigurnosnih sistema i demokratske vlasti, Foreign Policy Review, Vanjskopolitička inicijativa BiH, Broj 1, juni 2006, p. 205.

137 And this is precisely the context in which the United States today has an interest in Bosnia and Herzegovina. The fact that there was the war over twenty years ago, that the process of internal and external integration has not yet been completed, that the reform process and the construction of society and the state have not been fully implemented, in other words, the state still faces significant problems, and that as such can become a potential target of terrorist organizations and the source of instability in the region. This is exactly the direction of efforts on the post-war building of the Bosnian society. 
confronted with a number of foreign policy challenges - economic, political, security - and has lost interest in completing the work begun in Dayton. ${ }^{138}$

The Arab Spring, Libya, Syria, Iraq, Iran, Afghanistan, North Korea, and Russia ${ }^{139}$ have shadowed the genocide and ethnic cleansing in $\mathrm{BiH}$ and the agony that its citizens have been going through for the past two decades. Problems in the Middle East, terrorism and the preservation of the global US supremacy have set the foreign policy priorities of the United States in the other direction, far from BiH. Bosnia and Herzegovina has simply become invisible to US decision makers to such an extent that Europeans have become concerned that the United States might withdraw its troops from the region. ${ }^{140}$ Still, they were promised that this was not an option. Namely, in May 2001, the then Secretary of State Colin Powell, in an effort to reassure his NATO allies, said «we have started together and we will end together». ${ }^{141}$

However, as the policy of the United States towards the region and Bosnia and Herzegovina went through several phases, recently, at least declaratively, there has been an intensification of the US involvement in solving

138 KaPeTanović, A., Vanjska politika BiH - između izazova i slabosti, Buybook, Sarajevo, 2005.

${ }^{139}$ In recent years, the growing geostrategic breakthrough of the Russian Federation towards the West has been evident. It seems that Russia has embarked on a strategic offensive to take over control of this part of the Balkans, and uses Serbia and smaller BiH entity, Republika Srpska, for achieving this goal. In other words, Moscow has decided to take over from the US and the EU a complete primacy in Serbia and the Republic of Srpska. Russian geostrategic and geopolitical penetration into the heart of the Balkans and Europe has caused deep concern both in the EU and the USA and they are already trying to prevent the arrival of the Russians in all ways. Republika Srpska President Milorad Dodik is familiar with Russian plans and this is precisely the reason why he blocks reforms and constantly threatens with the referendum on the RS's secession from $\mathrm{BiH}$, for which has Moscow's tacit support. Russia sees Serbia and Republika Srpska as a bridge between Moscow and Brussels, just as Britain is a bridge between Europe and America. In addition, Russia uses Serbia and Republika Srpska as a pawn through which it would play a more important role on the global political stage. Recovered and strong Russia, with still live images of the humiliation that it experienced from the West in the 1990s, is now determined to show, but also use its strength. Therefore, tensions between Russia and the West will likely continue in the near future, as Russia today decisively protects its interests. Bearing in mind the increasingly aggressive policy of Russia towards Bosnia and Herzegovina, the European Union and the USA may have, at least for the sake of their own interests in restricting geostrategic and geopolitical penetration of Russia, be more actively involved in the situation in Bosnia and Herzegovina.

140 WoODARD, C., «In rebuilt Bosnia, no terror toehold», Christian Science Monitor, 24 March 2004, vol. 96 , Issue 82.

${ }^{141}$ Quoted in JosePH, E.P., Back to the Balkans, New York, Foreign Affairs, Council on Foreign Relations, jan/feb 2005, pp. 111-122. 
the remaining problems in Bosnia and Herzegovina. Although the current intensification of US activities in the Balkans can be put into the context of the broader US strategy in the fight against terrorism, as well as limiting the influence of Russia in this part of the world. It seems that the United States is ready, together with its European partners and allies, to firmly oppose all external destructive influences.

The first High Representative in Bosnia and Herzegovina, Carl Bildt recently stated that after September 2001, and especially after the crisis in Iraq, it is clear that «Europe and America have different priorities.» ${ }^{142}$ However, he claims that the experience from the Balkans shows that «these priorities are complementary and mutually supportive... the 1989 priority of peace through economic integration, political state building and the expansion of the rule of law goes hand in hand with the 2001 priority of the fight against global terrorism and the spread of mass destruction technologies.» ${ }^{143}$ Similarly, former US ambassador to the EU, Richard Morningstar emphasizes that if we look at the Balkans, Europe and America can «come to the conclusion that when we work together everything is possible; when we are on opposite sides, the progress is missing.» 144

Judging by the statements by top US officials, including former US Secretary of State Rex Tillerson, ${ }^{145}$ Vice President Mike Pence ${ }^{146}$ and until recently deputy assistant secretary of state for Europe and Eurasia, Hoyt Yee, ${ }^{147}$ the United States seem to be committed and determined to take a leading role in the Balkan region, i.e. together with partners from the European Union, to complete the project of security integration, democratic transition and the completion of reform processes in $\mathrm{BiH}$, in order for the country to prosper.

142 Quoted in GLIgorov, V., Iraq and the Balkans, WIIW Monthly Report, 3, 2003, p. 7.

143 BILDT, C., Peace Fourney, The Struggle for Peace in Bosnia, London, Weidenfeld and Nicholson, 1999, pp. 24-5.

144 Quoted in RHodes, A., Central Europe and Iraq: balance, bandwagon or bridge?, Orbis, 48(3), 2004, p. 423.

145 Tillerson Says U.S: Committed to European Security amid Russian Threat, Radio Free Europe, Radio Liberty, 28 November 2017, https://www.rferl.org/a/tillerson-european-security-russian-threat/28884642.html.

${ }^{146}$ Sewell Chan, Mike Pence in Montenegro Assures Balkans of U.S. Support, 2 August 2017. New York Times, https://www.nytimes.com/2017/08/02/world/europe/pence-montenegro-markovic-nato.html.

${ }^{147}$ YeE, H., Stability and Development of the Balkans are Extremely Important, Sofia News Agency, novinite.com, 15 January 2018, https://www.novinite.com/articles/187030/Hoyt+Yee\%3A+Stability+and+Development+of+the+Balkans+Are+Extremely+Important. 


\section{CONCLUSION}

Due to the inability to reconcile various, often contradictory, interests of the member states of the European Union with regard to important foreign policy issues, the common foreign and security policy of the European Union has so far achieved very limited results. Numerous challenges that Europe is facing today, from Brexit, financial instability, terrorism, migration crisis, Trump policies on one hand and Putin on the other, make it less possible for the European Union to achieve significant progress in the near future. What Europe needs today is strategically proactive thinking and predicting events, rather than reactive, often delayed postfestum action. There are a number of examples, such as Arab Spring, Brexit, migration crises, Crimea.

«... European Union needs strong visionary leadership who will be able to deliver anticipatory governance and improve the EU performance both internally and externally. The need for the EU to act strategically in order to endure and play a global role seems to become a common narrative in the broad European foreign and security community» ${ }^{18}$

Although respectable economic force, despite decades of efforts, it seems that the European Union does not even have today a strong and stable common foreign and security policy, which would allow it to be a respectable, credible and influential factor in global foreign policy and security issues. Thanks to its economic power, European Union could become a significant political force globally. «An EU of nearly 400 million people and a combined gross domestic product (GDP) of more than $\$ 8$ trillion that was able to unite its diplomatic and military potential could easily challenge the current status of United States as» lone superpower; «exert influence over the Middle East peace process and security in the Persian Gulf... and, perhaps most importantly, create a new balance within a NATO alliance that currently dominates the United States. ${ }^{149}$

Foreign policy is a multilayered, multidimensional and extremely complex area. Foreign policy, just like internal politics, is designed within the state,

\footnotetext{
148 Sus, M. (2017), Setting the scene for alternative future for European Union's foreign policy 2015, Futures 97 (2018) 1-5, Elsevier, Hertie School of Governance, Germany, European Union Institute, Italy.

${ }^{149}$ GoRdOn P. H., EU's Uncommon Foreign Policy, The MIT Press, International Security, vol. 22, No. 3 (Winter 1997-1998), p. 77.
} 
but unlike internal policy, it is directed and must be implemented outside the state. ${ }^{150}$ In fact, it represents behaviour of states vis-à-vis other states in the international system, and its main goal is the protection of national interests, ${ }^{151}$ as well as preservation, survival and strengthening of the state's power. ${ }^{152}$

Foreign policy is a blend of politics, diplomacy, economy, trade and security - primarily energy security. We must not neglect cultural, historical, civilization, and religious values and interests. In the end, we can say that «foreign policy is a complex result of a complex process. It is the result of the struggle of competitive issues, competitive domestic interests and competitive government agencies.» ${ }^{153}$ In other words, there are many, very different, internal interests that lead countries when formulating foreign policy. If we add to this a wider geopolitical context at a certain historical moment, the relationship among the great world powers, as well as their interests we will get an intricate bench of different factors that significantly influence formulation of the foreign policy of a state, and make it easier or more difficult to enforce it.

How is it possible then to formulate and implement common foreign and security policy of 28 different countries? In other words, how is it possible to reconcile and harmonize political, economic, security, cultural and all other interests of 28 different European Union member states, in a modern environment in which foreign and security policy of states is lead and directed exclusively by national interests? It is difficult, but not impossible.

Namely, as the borders of the European Union expanded, achievement of the common foreign and security policy seemed to be less and less possible. The process of establishing common foreign and security policy of the European Union was very painstaking; the EU passed a pivotal path to the establishment of the CFSP. Along the way, the European Union still experienced some progress and achieved good results, although not enough.

${ }^{150}$ White, B., Analysing Foreign Policy: Problems and Approaches, Hants: Edward Elgar, 1989, p. 5.

${ }^{151}$ Interest is the key word when it comes to the foreign policy of modern democratic states, including EU members and the biggest stumbling block in formulating a common EU foreign and security policy, since it is very difficult to reconcile the interests of 28 states. Winston Churchill once said: We have no lasting friends, no lasting enemies, only lasting interests. https://www. azquotes.com/quote/1421008, accessed 27 August 2018.

152 JANEV, I., Međunarodni odnosi i spoljna politika - sa primjerom jugoslovenskih odnosa sa Ujedinjenim nacijama, Institut za političke studije, Beograd: Čigoja štampa, 2002, pp. 16, 68-79.

${ }^{153}$ Howell, W.; Pavenouse, J.C., While Dangers Gather: Congressional Checks on Presidental War Powers, Princeton University Press, 2007, p. 147. 
How can the European Union achieve remarkable results in this area? What would it be a common denominator and a motivating factor in the establishment of CFSP? The answer is very simple and can be summarized in a few words - a policy guided by moral principles. It seems that moral principles and ethical values are completely marginalized or even lost in this modern world in which we live. Although it sounds utopian, the policy guided by moral principles, which aims at the well-being of all humanity, can only and truly be the generator of a positive change, not only in the area of common foreign and security policy, but also on the global stage.

In order to achieve this, it is necessary to reject small, or not so small, individual, particular interests and resolutely start working in a spirit of communion for the benefit of every human and every nation, at all times ready to compromise, ready to come out of our own perspective and even more resolutely ready to look at every problem and situation from multiple perspectives, working of course in our own interest, but respecting the fears, will, desires and interests of others.

This, of course, applies to the common foreign and security policy of the European Union towards Bosnia and Herzegovina as well. The situation in Bosnia and Herzegovina today, two decades after the end of the brutal war, is very complex and burdensome with many problems. The society and the state are faced with a number of serious challenges that threaten to endanger the very existence of the state. Different, ruling political options in $\mathrm{BiH}$ have different, very contradictory interests, which, unfortunately, are not aimed at strengthening the state of Bosnia and Herzegovina and the prosperity of all the people living there. We, the citizens of Bosnia and Herzegovina cannot solve these problems by ourselves, nor can we get out of this situation. Despite the significant involvement of the European Union in Bosnia and Herzegovina throughout its entire modern history, from the beginning of the 1990s to the present, $\mathrm{BiH}$ has failed both to build a democratic society and a stable prosperous state, and to adopt modern European standards in many segments of society and the state.

To achieve this, we need help and support of modern, democratic European countries, a more determined engagement of the European Union, today more than ever before, because of the future of the citizens of Bosnia and Herzegovina, and all citizens of the European Union. 